\begin{abstract}
Abdou Labo Bouché \& Antoinette Tidjani Alou

Abdou Labo Bouché teaches in the

Department of English at the Abdou Moumouni University in Niamey; Antoinette Tidjani Alou teaches French Literature, Comparative Literature and Literary Criticism, in the Department of Modern Literature at the same university. She is a member of the research group on "Literature, Gender and Development. Nigérien Visions and Perspectives".

E-mail:1abo57ma@yahoo.fr; mata@intnet.ne
\end{abstract}

\title{
Language use and literary onomastics as markers of identity in the Nigérien novel
}

Nigérien literature written in French is not widely known outside of French-speaking Africa, and even there, only in certain milieus. This is due in part to its relative newness, dating from the beginning of independence, around 1960. However, the main reason concerns the low level of productivity. Moreover, many works remain at the level of manuscripts since access to publishing is not easy: local publishers are non-existent, while local printers find little interest (i.e. profit) in this emerging literature in a country where the reading population is minimal, as most Nigériens are illiterate. Nonetheless, some Nigériens do engage in literary writing and their works demonstrate certain specific traits. In opposition to the pan-African interests and orientations of first-generation francophone African writers like Léopold Sédar Senghor, Birago Diop and Mongo Beti, Nigérien writers, on the whole, have a tendency to concentrate on issues of local social, political and cultural importance. Themes range from the denunciation of past regimes to various aspects of the processes of social change underway. An examination of Mahamadou Halilou Sabbo's Abboki, ou l'appel de la côte (Abboki, or the call of the coast) and Caprices du destin (Destiny's whims) provides an interesting point of entry into an overview of the relation between language use and character construction on one hand, and the processes of national identity construction on the other. Key words: Nigérien novel, Niger, Hausa, identity, onomastics, Hausa proverbs, migration, myth of the "coast".

\section{Introduction}

Nigérien literature written in French is not widely known outside of French-speaking Africa, and even there, only in certain milieus. This is due in part to its relative newness, dating from the beginning of independence. However, the main reason concerns the low level of productivity. Moreover, many works remain at the level of manuscripts since access to publishing is not easy: local publishers are non-existent, while local printers find little interest (i.e. profit) in this emerging literature in a country where the reading population is minimal, since eight out of ten Nigériens are illiterate. 
Nonetheless, some Nigériens do engage in literary writing and their works demonstrate certain specific traits (see Constanty, 1991: 110; Issa Daouda, 1993; Penel, 1991: 108). In particular, as opposed to the panAfrican interests and orientations of first-generation francophone African writers like Léopold Sédar Senghor, Birago Diop and Mongo Beti, contemporary Nigérien writers, on the whole, have a tendency to concentrate on issues of local social, political and cultural importance. Themes range from the denunciation of past regimes to various aspects of the processes of social change underway.

An examination of Mahamadou Halilou Sabbo's Abboki, ou l'appel de la côte (Abboki, or the call of the coast) and Caprices du destin (Destiny's whims) provide an interesting point of entry into an overview of the relation between language use and character construction on one hand and the processes of national identity construction on the other.

Nevertheless, the question of identity is particularly complex even when considered at the individual level. This complexity is exacerbated when the matter is seen from the collective perspective of the group, the region or the state (nation). On one hand, there is the problem of providing broad-based analysis on a situation in a state of constant change. Moreover, several subjective and ideological elements intervene producing a plethora of unspoken and often nebulous working definitions. It then becomes difficult or impossible to be engaged in any discussion, however general, of the relationship between literary writing within the limits of national borders and the construction of a "national identity".

For the purposes of the present discussion, we could define identity, in a very classic manner, as " an organized set of representations, knowledge, memories and projects concerning the self, that is, concerning the person as a psychological being, who acts, knows himself, and feels within the world" (Lirus, 1979: 10). ${ }^{1}$

This definition, under the guise of various formulations, has a tendency to put emphasis on the individual, psychological, subjective and voluntarist aspects of identity. However, it provides a useful starting point for the discussion of identity and the literary work, especially when the latter is seen from the perspective of the writer. Moreover, it does not cloud the collective facets of identity, linked to group phenomena like conceptions and social projects or ideals though these are also seen here as projections of the self. Consequently, this type of definition could be rebalanced by

(a) including or underlining the importance of the constraints of 
the socio-cultural milieu in which the individual evolves in relation to other individuals as a member of various "social networks" - groups and interpersonal relationships (he or she is both actor and acted on);

(b) highlighting, alongside individual psychological factors, collective archetypes, or the influence of the subliminal elements of primeval collective "memory" and mythical conceptions (a Jungian approach);

(c) taking into account - in the specific case of literary writing in Niger - the fact that identity is also the product of various types of discourses, actions and interpretations: individual, official (of the state, etc.), and academic: "it is a cultural, political or ideological construct (...) in fine a historical construct" (Bayart, 1996: 10). ${ }^{2}$

The present overview of two of Mahamadou Halilou Sabbo's novels addresses some of the ways in which the Nigérien novel is related to identity construction as defined above. We would like to insist on the fact that what we are attempting here, briefly, is to underscore some of the markers of identity in the Nigérien novel and not some of the markers of Nigérien identity. This emphasis is not gratuitous. Indeed, the construction of Nigérien identity is at the embryonic stage. There is nothing surprising about this: forty-four years after independence a nation is yet unborn, in a manner of speaking. But before the tracing of current national borders, several local identities, evolving in the context of more or less interrelated chiefdoms, emirates and empires did exist within the spaces redefined as the Republic of Niger in 1958, prior to independence. Consequently, contemporary Nigériens - and writers among them - bear witness to regional identities while contributing to the construction of a national identity which will, in all probability, have to be build on this foundation it if is to succeed.

\section{Abboki, ou l'appel de la côte or Nigériens dreaming of Eldorado}

Abboki, ou l'appel de la côte was written in 1980 and published by the Nouvelles Editions Africaines, in the Ivory Coast. The novel is preoccupied with the chronic problems of drought in Niger, added to the pressures of the colonial period in which the novel is set. These conditions are jointly responsible for the myth of the coast, to which many oral productions such as women's pounding poems attest.

The hero Amadou, fed up with the multiple exactions of the colonial state and with crippling tax collection in particular, decides to 
migrate to Abidjan, capital of the Ivory Coast. This, to his mind, is the regional Eldorado. Dreams of quick fortune fuel his migration plans and his hopes of social mobility. Why shouldn't he be like some of his more fortunate elders who

(...) came back home totally transformed, no longer looking like country bumpkins (...) Every morning, they rambled through the streets of the village in their Sunday-best, like important traders (...) Every evening, dancing to tam-tams was organized. This offered to each of them the opportunity to show off the fortune that he had amassed during his expedition. In fact, bank notes flew around all over the place, then fell scattered to the ground of the dance circle (Halilou, 1979: 9-10). ${ }^{3}$

This short passage contains an effective résumé of the pre-colonial and current socio-cultural values, which along with the vital question of earning a livelihood; motivate the massive seasonal migration of Nigérien men, in particular landless males from the rural areas. It is interesting to note that the colonial parentheses did nothing to erase the values that we will now highlight briefly. Our young hero, Amadou watches enthralled as, during the celebrations of the newly rich who have returned home, bank notes are thrown lavishly into the dance circle both to congratulate the dancers' prowess and to demonstrate wealth and generosity: two distinctive traits of local aristocrats. Hence, what Amadou is in fact attracted to is not just bread and butter, but access to the means of displaying the ostentatious generosity of Nigérien princes and princesses.

The focus here is on the socio-cultural and economic circumstances that motivate the migration of able-bodied rural men. For every Baadaré - inhabitant of the Ader region in Western Niger, the author's milieu of origin - emigration to "the coast" or to some other destination abroad is, moreover, a must; something like a contemporary mode of initiation: to become a man, you have to have been there. According to such more or less contemporary traditions, by the age of thirteen, and after the harvest, a teenager has to go on a quest (Bida in Hausa, meaning "to hunt, to labour for money"), as mentioned in the introduction of the novel: "So, every year, after the harvest and sometimes even before, many of our provinces are drained of their youngsters (...). Toiling under the illusion of escaping from the misery of their abode, they migrate to towns on the coast, in search of a better future" (Halilou, 1979: 5). ${ }^{4}$ 
In fact, the Adarawa - plural of Baadaré - are well known for their courage and determination when it comes to migrating to earn money. In this local society, but also in others, men are expected and encouraged to leave their wife or wives, children, parents and kin to go abroad to make money. But this conception and behaviour is also noted in other milieus. Women's working songs and their pounding poems in particular, attest to the hopes invested in the proceeds of migration. The able-bodied male who does not migrate seasonally is held in contempt, through the indirect medium of pounding poems; while the migrant who fails to make it, or comes home penniless is insulted as a liar, as in the following extract from one such poem, revealing the bitter deception of a migrant's wife:

These people coming back from the Coast are all liars:

No Custom Officer has ever seen them,

But whoever comes home penniless,

It's the Customs Officer who stripped him clean.

(...)

Sanda is back, he's become a real big-shot,

The Customs Officer didn't catch him.

The lucky ones got through

While the Customs Officer was taking his bath. ${ }^{5}$

\section{Caprices $d u$ destin or memories of the colonial period}

Set in the Tahoua (Western Niger) region, towards the end of the colonial period and the beginning of multipartism, Caprices $d u$ destin (1981) is probably Mahamadou Halilou's most accomplished work. The novelist explores the violence and power struggles involved in colonial social relationships. Characters like Kasko, Gagéré and Gamji, provide insight into some aspects of Nigérien society at an important period, characterized by brutal historical events and attempts at developing infrastructure. Fictional events mentioned in the novel such as the construction of the road from Garin-Kowa to Tajayo, through forced labour; school registration in rural areas, through violent methods; the electoral campaign prior to the referendum that was to decide on the option for independence. For the oui (yes) or the non (no), also marked by coercion, mirror real events of a similar variety. Some of the main characters such as Goumaibe, the commandant or Kafi-Rana-Zahi, the guard also represent the violence and discrimination experienced but also exercised, in some cases, by certain members of the local population and by colonial rulers during the period in question. (A topic 
explored by Amadou Hampaté Bâ in his novel L'Etrange destin de Wangrin (Wangrin's strange destiny, 1973) and his memoirs, "Oui, mon commandant" (Yes, my commandant, 1992). In his preface to Caprices $d u$ destin Issa Ibrahim, a first-generation Nigérien author (inter alia the first Nigérien "novel" Les grandes eaux noires (The great black waters, 1959) affirms: "As far as we can see, Mahamadou Halilou demonstrates undeniable intellectual probity, an acute analytical sense in his treatment of the periods evoked. His perfect neutrality in the evocation of events which brought various tendencies or political factions up against one another, classifies him among those who are from no period, and no country" (Ibrahim in Halilou, 1981: 5). ${ }^{6}$

In Caprices $d u$ destin socio-cultural, economic and historical facts are of importance to the central narrative even in the case of fictional (as opposed to "historical" characters). Abrams (1985: 120) notes this type of preoccupation in the African novel. Narration often focuses on the events of everyday life, related by the hero or by another character. As Chaibou Dan Inna (1993: 17) mentions, the Nigérien novel "informs us of our social, political and cultural environment". ${ }^{7}$ A good understanding of the socio-cultural context is therefore essential to the interpretation of Mahamadou Halilou's novels. However, language use is also an important ingredient of Halilou's creativity, on one hand; on the other, it also provides valuable insight into the links between literary creativity and cultural and ethnic identity in Niger.

\section{Literary onomastics}

Language and its various uses are obviously related to the cultural identity of a group or society. According to Saussure, "language is the implicit system of elements, of distinctions, oppositions, and of principles of combination shared by members of a language community, which make it possible for a speaker to produce, and the auditor to understand, a parole" (quoted in Abrams, 1985: 215, original emphasis).

This situation is somewhat modified and made more complex when language becomes writing. That is, when it is no longer a question of direct oral communication, but of mediated communication of a special kind. The written text is directed, at the same time, to two different sets of readers who have two different mother tongues. There are on the one hand, fellow citizens from the author's milieu of origin, with whom he shares a mother tongue, which is not the language of his written text, notwithstanding his desire to maintain a special relationship based on complicity with this select public. On the other hand, 
there is an anonymous, virtual public of francophone individuals, local and international to whom the work is also destined.

Before discussing some of the implications of this situation, it is important to note that Halilou's writing conveys meaning through the insistent use of anthroponyms from the Hausa language as well as a massive, overwhelming use of Hausa proverbs translated, loosely or closely, exactly or otherwise into the French language. These language manipulations are transparent to speakers of the Hausa language, be they mother-tongue users or not. But the relation between the text in French and original Hausa references is not limited to what we construe as the writer's efforts to create a special relationship with Hausa speakers based on a sense of complicity (shared identity). There is also a perceived auctorial desire to introduce into the work, written in French, the flavour, humour, irony and worldview of a familiar environment in a text whose language medium - French, Niger's official language creates a certain distance between the writer and his creation, on one hand, and between the writer and his privileged readers, on the other.

This appears to be important. In fact, francophone African writers are often taken to task for writing primarily "for the other", for "the outside". Consequently, it is not unimportant to note that this tendency, however real, is not homogenous. It coincides with other tendencies aimed at a special communication with readers from the writer's own country and region. It would appear that such tendencies are even predominant in certain writers. All in all, attempts are made to bridge the gap between the cultural life-worlds and worldviews explored in the works under discussion.

We will attempt to illustrate some of these elements with the help of a sample of commented Hausa anthroponyms and proverbs that appear in Mahamadou Halilou Sabbo's novels.

\section{Anthroponyms}

"Abboki", a masculine common noun meaning "friend", is the nickname given a character of the novel and features in its title. There is an interesting comment on one of the relational uses of naming, on page 26 of the novel. When a certain individual from Abidjan uses the word "abboki" as an insult to the foreigner from Niger, saying, "Dirty Abboki! Thief! Miscreant (...) you are a set of parasites! (...) Thrash (...)" our migrant is shocked. For the Ivorian in question, he is neither a "friend" nor an African brother, but an undesirable alien. Abboki offers the ineffectual explanation, "The word Abboki means friend in my language." 
But he is set straight by a friend, Madougou, "For the people in this country, you are abboki, inferior beings, without upbringing". 8

In the world of exile, meanings and values are inverted, and the individual in exile, in the search for upward social mobility, sacrifices his sense of belonging and dignity. Kasko is the hero of Caprices $d u$ destin. The term has a double meaning. Firstly, it means a potsherd used to collect glowing embers. Secondly, it refers to the pot in which women prepare bean cakes or peanut oil. As implied metaphorically in his "name," Kasko is more often than not in a "hot spot". As a primary school teacher, he is theoretically an important local personality, a village VIP. But his communist conceptions and his perpetual conflict with both the white and black "commandants," the overlords of the colonial era, disqualify him as a representative of the local (village) administration. Kasko is a born loser who never manages to get on the right side of the political fence, neither before nor after independence. Our protagonist, who naïvely believes that he can change the world by the power of argument, is therefore always disappointed: if not by the lack of interest in pan-African politics, then by the lack of interest in formal education. (The village chief and village leaders take up a collection to pay the bribe needed so that their children will escape registration in the colonial school.) Instead of the reward promised, Kasko is jailed following a military coup.

"Madougou", in Hausa, refers to the person in charge of an expedition. In Abboki, ou l'appel de la côte he incarnates many positive values. The veteran of emigration to "the coast", he is, in the land of exile, the leader, advisor and protector of his fellows. His standpoint on the achievement of independence is very pragmatic, as illustrated in the following exhortation to fellow migrants:

My brothers, we need to understand life. We, as people from the country, are born to suffer. They are always going on about the advantages of independence. We were happy; we said: abuse, corruption, oppression and humiliation are over, since the coloniser has gone. Power in now in the hands of our brothers. Unfortunately, as you can see, all that was only an illusion (Halilou, 1979: 19). ${ }^{9}$

In compliance to the contemporary social dynamics of Nigérien society, the Hausa title "Madougou" takes on a new meaning, but the leadership role of the character so named remains important.

"Kafi Rana Zahi" is an invented, satirical, Hausa compound name meaning "you're hotter than the sun". Security guard to the French 
representative of colonial power, the "commandant", he seems to wield even greater power than the "commandant" himself, as suggested, with humour and irony, in the following extract:

Kafi Rana Zahi, the (commandants') guard will be coming (...) to Korzalé (...) Since the day before, all of the young people have busied themselves with the transportation of (...) a hundred bundles of straw, a hundred pots of water, a hundred mats; and twenty young men are ready and waiting to serve the guard's horse. The villagers have prepared a specially chosen spot to stable his horse, which the young girls from the village spent hours sweeping. After the sweeping, they took particular care in picking up all the pieces of stone and wood, which might harm the extremely sensitive skin of Kafi Rana Zahi's horse. Ten old women spent the entire morning sifting the millet that was to be eaten by this horse (Halilou, 1981: 14). ${ }^{10}$

But attention must be also be paid to the man, not only to his horse. However, when the narrator is forced to relate extreme and reprehensible abuse, description gives way to direct speech: we hear the details from the "horse's mouth" rather than via a moral discourse: "'prepare ten of the prettiest young girls to keep me company,' demands the local overlord, 'Some will massage my body and the others will allow me to enjoy the delicious sensuality of their nubile bodies'" (Halilou, 1981: 15). ${ }^{11}$ Despite the fact that violence, expropriation and sexual abuse characterize this infamous character, the author manages, overall, a dispassionate and even humorous portrait.

We may note, in parentheses, that this approach is characteristic of his treatment of the violence exerted, directly or indirectly by the French commandant and his immediate entourage. In the same novel, when the commandant's wife looses her beloved dog, Prince, a lavish funeral service is prepared; tears are required from one and all, and delivered to order:

"Prince," Madame's beloved dog died (...) Goumaibe, in full regalia, appeared on the threshold of the residence holding the hand of Madame, dressed in black (...) two guards carried the dog on a stretcher covered with bouquets of flowers (...) The mortal remains were laid down in a corner. A hole was dug (...) Sumptuous carpets were laid down to receive the corpse. When it was being lowered into the tomb, Birga ordered the bugler to play the last post and the guards presented arms (...) Madame burst into sobs, the civil servants and the guards did likewise" (Halilou, 1981: 14). ${ }^{12}$ 
The author's success in treating such events dispassionately might be due in part to the period in which the novel is written - in 1980, twenty years after independence. Authors of the previous generation, understandably, often brought considerably more pathos to the description of this kind of situation. Notwithstanding, the violence involved in the various relationships evoked remain patent, despite the de-dramatisation wrought by humour, and the distance it implies, attesting to human resilience in the face of trauma, to the healing powers of time and to an "existential art" (Escarpit, 1960: 127).

"Idon-Gari" is the nickname villagers give to the commandant's spy in Caprices $d u$ destin, meaning literally "the eyes of the town", the role of this character is to keep the commandant informed about everything that happens everywhere.

"Gamji" is the name of headmaster of the school in Garin-Kowa. His name is symbolic of his fame in the village. The gamji (ficus playphilia del. Moraceae) is in a fact a giant tree used symbolically to evoke the power attributed to traditional chiefs. The name subtly evokes aspects of the power shift introduced by colonisation and one of its corollaries, the introduction of a more or less (usually less) French style of formal education. Due to this type of social dynamics, schoolteachers, and the headmaster in particular, become local leaders or "big men", people of (not necessarily inherited) power.

The Hausa language is used to name various other characters. Typically, proper human anthroponyms of past or current use in that language are not employed. Along with nicknaming - a common relational strategy with varying objectives - common nouns designating domestic objects, animals (particularly folktale characters) are called into service. Below are a few, final, examples:

(a) The marabout in Caprices du destin is dubbed "Gobédanissa", meaning literally, "tomorrow is far away." The implied menace gives a negative charge to this "man of God", who, in a local syncretic practice of Islam-cum-animism, is portrayed in the universe of the novel as a sorcerer wielding fear-inspiring mystical powers.

(b) Other important figures include "Dague", the griot, in Abboki, ou l'appel de la côte whose nickname in Hausa designates a small wildcat. Once again, this character, negatively portrayed, fits the contemporary image of the griot: a degenerated remnant of the original function as the chief's bard and genealogist.

(c) "Toulou", an earthenware water-pot is the nickname of the commandant's interpreter (his mouth), also called "Maji-Magani", 
literally "we will hear, we will see". This character type was, in the colonial administration, an indispensable personality, a bridge of communication, and, obviously, a local big-man, who reaped and probably paid for the dividends of power, and power abuse, derived from his privileged position.

(d) Finally, two tricksters in Caprices du destin are called "Guizo" and "Zomo" - the spider and the hare respectively - two popular folktale figures of similar temperament.

\section{On proverbs and power}

The Hausa reader of Mahamadou Halilou's novels is aware of an extensive use of Hausa proverbs by the author (44 proverbs in both novels). This brings to mind the Nigerian novelist Chinua Achebe who maintains that proverbs are like okro soup (an unctuous, slippery sauce served with great liberality) with which food (like pounded yam) is eaten. We could translate: proverbs help wisdom to penetrate pleasantly. They are obviously concentrated résumés of wisdom, served up in familiar terms, lubricated by irony, understatement, various registers of humour, and so on. Mahamadou Halilou Sabbo's proverbs constitute the framework of his novels. As opposed to his onomastic strategies, the proverbs in both novels are in French, although their origin in Hausa is clear to speakers of this language.

Though proverb use is apparent in both Abboki, ou l'appel de la côte and Caprices $d u$ destin the second novel makes a more intensive use of this popular expression, eight of the 44 proverbs we counted. In both cases, proverbs cover a wide variety of intersecting types: proverbs edicting norms of behaviour, others entailing rules and observations concerning social interactions and social hierarchy, principles of power and attributes of leadership, sentences concentrating on moral values and conceptions, popular wisdom, everyday pragmatism and such like. It is clearly impossible either to list or to discuss all of these individual proverbs or types of proverbs. As most proverbs occur in Caprices $d u$ destin this part of our discussion will focus almost exclusively on this novel. In the interest of coherence, we will concentrate on proverbs addressing relationships surrounding social hierarchy and power. We will limit ourselves to a selection of a dozen proverbs, listed as they occur in French in the text along with the Hausa original and a translation into English. 


\section{Attributes of power}

The following proverbs allude to the attributes of power.

a) French: "Le bois pouvant servir de manche se reconnaît à première vue" (Halilou, 1981: 40).

Hausa: "Icen dake shishiniya ansanshi."

English: You can't miss a good thing (literally: it is easy to recognise the wood that makes a good handle.)

b) French: "Quand le soleil apparaît, impossible de le cacher avec la paume de la main" (Halilou, 1981: 112-113).

Hausa: "In rana tafita, tafin hannu bai kareta."

English: You can't hide the sun with the palm of your hand.

c) French: "Même si la rivière tarit, le caïman surpasse la gueuletapée" (Halilou, 1981: 107).

Hausa: "Ko ruwa sunkare, kada yawuce su."

English: Though the river runs dry, the caiman will never meet his match.

d) French: "Ĺocéan renferme d'énormes quantités d'eau, cependant il ne dédaigne guère que des rivières viennent le grosser" (Halilou, 1981: 103).

Hausa: "Ko gulbi yana son kari."

English: Though the ocean is rich in water, it will not refuse the increase that the rivers bring.

e) French: "Le riche est l'ami du roi" (Halilou, 1979: 21).

Hausa: "Mai Kudi abokin sarki"

English: The rich man is the king's friend.

The prevailing conception is that signs of power are unmistakable or better yet overwhelmingly obvious, inherent or "natural", irrepressible and insurmountable. However, this positive elitist conception is re-balanced and questioned by proverbs number four and five which propose a more pragmatic conception of the criteria of power and the means of entering into the graces of the powerful. Such contradictory conceptions, with a progressive leaning towards the last, seem to be prevalent in contemporary Niger.

\section{Responsibilities and prerogatives of the powerful}

Along with certain attributes, people of power (usually men of power) enjoy certain prerogatives and must in turn attend to certain responsibilities, some of which are evoked in the following proverbs: 
f) French: "Quand vous entendez une vache beugler, c'est qu' elle a aperçu celui qui lui donne à manger" (Halilou, 1981: 84).

Hausa: "In kaji saniya na kuka, taga mai bata abinci."

English: The cow is lowing, it's feeder has come.

g) French: “Lorsqu' un animal a soif, il court vers la mare” (Halilou, 1981: 101).

Hausa: "In dabba nason ruwa, gudu take zuwa tapki."

English: When an animal is thirsty, it runs to the pond.

h) French: "Quand on n'a pas atteint la maturité d'un bouc, il ne faut pas vouloir puer comme lui" (Halilou, 1981: 122).

Hausa: "In ba'a cika bunsuruba abar wari."

English: If you are not a mature he-goat, try not to not smell.

i) French: "De qui vous moquez-vous ? De celui que je vois tous les jours" (Halilou, 1981: 87).

Hausa: "Ido wa kuka rena? Sukace, wanda muke gani kulum." English: Who are you making fun of? The person we see everyday.

To maintain respect, persons of power must observe a certain reserve. For, as proverb (i) underlines, familiarity breeds contempt. Moreover, privilege and power go hand in hand: the mature ram - and he alonehas the right to exude a virile odour. But he must prove his virility (translate "power" in the broad sense of the word) by aiding and protecting those in need. Consequently, not only the chief, but any individual considered as powerful, in one way or another, financially being an obvious criterion among others, is expected to correspond, in Nigérian societies, to this proverbial typology, in a very practical, and continual, manner.

\section{The dangers of power}

Every silver lining announces a cloud: power also goes hand in hand with danger, including that of provoking hostility and isolation, as these final proverbs imply.

j) French: "Lorsque le bras a failli, on en punit la tête" (Halilou, 1981: 44).

Hausa: "In hanu yayi kure, kai keda laifi."

English: If the hand is mistaken, the head is punished.

k) French: "Quel mal y a-t-il si le margouillat consomme le mil du caïman? (Halilou, 1981: 98).

Hausa: "Laifine kadangare yaci hatsin kada?"

English: What do we care if the lizard eats the caiman's millet? 
1) French: "Quand tu tues un serpent, enlève-lui la tête" (Halilou, 1981: 103).

Hausa: "Kowar kashe maciji, ya fitar da kan."

English: If you kill a snake, cut off its head.

\section{Conclusion}

Language and its various uses are related to the cultural identity of a group or society. It is therefore follows that literary writing within the limits of national borders can be considered in relation to the construction of a "national identity".

However, identity, which concerns both the self and society, is, as we will admit, a very complex concept, and this complexity is further exacerbated when the matter is seen in the collective perspective of the group, the region or the state (nation).

The preceding overview of two of Mahamadou Halilou Sabbo's novels has attempted to address some of the ways in which the Nigérien novel is related to identity construction and to highlight some of the markers of identity in the Nigérien novel. Visible in anthroponyms and other onomastic features, but also in proverbs translated from the Hausa language, many of these markers of local and regional identity are linked both to contemporary reality and to values and symbolism (evolving in the precolonial and colonial context of more or less interrelated chiefdoms emirates and empires) pre-existing the tracing of current national borders.

Hence, language, related to Halilou's creativity, also provides valuable insight into the links between literary creativity and cultural and ethnic identity in Niger, on one hand. But it also regards the relationship between such creative and identity processes and the historically generated relationship to the cultural "other", incarnated in for example, the French language. Here, literature becomes, among other things, mediated communication of a special kind in which the written text is directed, at the same time, to two different sets of readers, having two different mother tongues: fellow citizens, on one hand, and an anonymous, virtual public of francophone individuals, local and international, on the other. The reader distinguishes a manifest auctorial desire to introduce into the works, written in French, the flavour, humour, irony and worldview of a familiar local environment in a text whose language medium - French - creates a certain distance between the writer and his creation, on one hand, and between the writer and his privileged readers, on the other. 
However, as we have noted, the use of French does no always determine writing "for the outside" or for "the other". It often coincides with other tendencies aimed at a special communication with readers from the writer's own country and region; with conscious attempts to bridge the gap between various interrelated cultural life-worlds and worldviews.

\section{Notes}

1. “un ensemble organisé de représentations, de connaissances, de souvenirs et de projets se rapportant au soi, c'est-à-dire à la personne psychologique, agissante, se connaissant, et se sentant dans le monde" (Lirus, 1979: 10). All translations, unless otherwise stated, are ours.

2. "une construction culturelle, politique ou idéologique, c'est-à-dire, in fine, une construction historique" (Bayart, 1996: 10).

3. "Ils revenaient au pays totalement transformés, ayant perdu leur air campagnard.... Chaque matin, ils parcouraient les rues du village endimanchés tels d'importants commerçants... Tous les soirs des tam-tams s'organisaient. L'occasion s'offrait ainsi à chacun d'eux d'étaler la fortune qu'il avait amassée au cours de son périple. En effet, les billets de banque tourbillonnaient de partout et jonchaient le cercle des danseuses" (Halilou, 1979: 9-10).

4. "Ainsi chaque année, après les récoltes et même parfois avant, plusieurs de nos régions se vident de leurs bras valides... Ceux-ci, pensant fuir la misère du terroir natal, partent en quête des lendemains meilleurs vers les villes de la côte" (Halilou, 1979: 5).

5. "Yamma-ize ga taari no/ Dugunye mana di-ey/ Boro mana kande su/ Ma ne dugunye na ni fatwa/ (...)/ Sanda kabey-ga/ Dugunye man di-a/ Bonkaanay ka te/ I ka ga gar dugunye koy nyumay." This poem, performed by Sadi Hadi, transcribed by Boureima Souley Gado, translated in French from the Zarma original by Fatimata Mounkaila \& Diouldé Laya, is quoted with the courtesy of the Women Writing Africa West/Africa Sahel, a project of the Feminist Press, at the City University of New York, funded by the Ford and Rockefeller Foundations.

6. "Pour le moins qu'on puisse apprécier, Mahamadou Halilou fait preuve d'une probité intellectuelle incontestable, un sens très aigu dans l'analyse des périodes évoquées. Sa parfaite neutralité dans l'évocation d'évènements ayant confronté durement maintes tendances ou factions politiques le situe dans la lignée de 'ceux qui ne sont d'aucun temps, et d'aucun pays" (Ibrahim in Halilou, 1981: 5).

7. "le roman nigérien nous informe sur notre environnement social, politique et culturel" (Dan Inna, 1993: 17).

8. “sale Abboki! Espèce de voleur. Mécréant, (...) Vous êtes des parasites! (...) Vilaines vermines (...) Le mot Abboki signifiait ami dans ma language (...) Vous êtes des abboki pour les gens d'ici, donc des êtres inférieurs, sans la moindre éducation" (Halilou, 1979: 26).

9. "Mes frères, nous devons comprendre la vie. Nous autres campagnards, nous sommes nés pour souffrir. On nous a toujours vanté les bienfaits de l'indépendance. Heureux, nous disions finis les abus, la corruption, les brimades et les humiliations, puisque le colonisateur était parti. Nos frères détiennent à présent le pouvoir. Malheureusement, comme vous le constatez, tout n'est que vaines illusions" (Halilou, 1979: 19).

10. "le garde Kafi Rana Zahi viendra (...) à Korzalé (...) depuis la veille tous les jeunes du village se mobilisèrent pour transporter (...) Cent bottes de pailles, cent canaris d'eau, cent nattes et vingt jeunes gens prêts à servir le cheval du garde. En guise d'écuries, on aménagea un endroit spécialement choisi que des jeunes filles balayèrent des heures durant. Après le balayage, celles-ci mirent un soin tout particulier à ramasser les morceaux de cailloux et de bois pouvant blesser la peau fort délicate du cheval de Kafi Rana Zahi. Une dizaine de vieilles femmes passèrent toute la matinée à tamiser le mil qu'il mangera" (Halilou, 1981: 14).

11. "prévoyez dix jeunes femmes et des plus belles pour me tenir compagnie. Certaines me masseront le corps et les autres me permettront de savourer la délicieuse volupté de leurs corps nubiles" (Halilou, 1981: 15). 
12. "'Prince,' le chien choyé de Madame mourut (...) Goumaibe en habits d'apparat apparut sur le seuil de la résidence tenant par la main Madame en tenue noire.. deux gardes transportèrent le chien sur un brancard couvert de bouquets de fleurs (...) On déposa dans un coin la dépouille mortelle. On creusa une fosse (...) On y étala de somptueux tapis pour recevoir le cadavre. Au moment de le descendre dans le tombeau, Birga ordonna au clairon de jouer la sonnerie aux morts et les gardes présentèrent les armes (...) Madame éclata en sanglots, les fonctionnaires et les gardes firent autant" (Halilou, 1981: 14).

\section{Bibliography}

Abrams, M.H. 19855. A Glossary of Literary Terms. New-York: Holt, Rinehart and Winston Inc.

Bayart, Jean-François. 1996. L'Illusion identitaire. Paris: Fayart (L'espace du politique).

Dan Inna, Chaibou. 1993. Présentation de la littérature Nigérienne moderne. Ecriture, 42: 11-21.

Halilou Sabbo, Mahamadou. 1979. Abboki ou l'appel de la côte, Dakar: NEA / Edicef. 1981. Caprices du destin. Niamey: INN.

Constanty, Michel. 1991. Le roman nigérien. Originalité du dialogue. Notre Libraire, La Littérature Nigérienne 107: 110-114.

Escarpit, Robert. 1960. L'Humour. Paris: PUF.

Issa Daouda, Abdoul-Aziz. 1993. La Double tentation du roman nigérien. Unpublished doctoral dissertation. Montpellier III: Université Paul Valéry.

Hunter, Linda \& Oumarou, Chaibou. E. 2001. Aspects of the Aesthetics of Hausa Verbal Art. Cologne: RK Verlag.

Lirus, Julie. 1979. Identités Antillaises: Contribution à la connaissance pyschologique en anthropologique des Guadeloupéens et Martiniquais. Paris: Editions Caribéennes.

Moussa, Mahamadou \& Issoufou, Rayalhouma. 1996. Anthologie de la littérature écrite nigérienne d'expression française. Saint-Amand-Montrond: Sépia.

Mphahlele, Ezekiel. 1974. The African Image. New York: Praeger Publishers.

Ngara, Emmanuel. 1985. Art and Ideology in the African Novel. London: Heinemann.

Penel, Jean-Dominique. 1991. Littérature et politique. Notre Libraire, La Littérature Nigérienne 107: 104-109.

Taiwo, Oladele. 1986. Social Experience in African Literature. Enugu: Fourth Dimension Publishers. 